\title{
Emil Radok and The Taming of Demons
}

\author{
By Jiř́i Voráč
}

Spring 2003 Issue of KINEMA

\section{EMIL RADOK AND THE TAMING OF DEMONS: THE CZECH INVENTOR OF THE MULTI-SCREEN SHOW IN CANADIAN EXILE}

In the Cold War era Canada was one of the main destinations of anti-Communist exile where many Czechs (and Slovaks) from the film domain found asylum. In particular, the strong wave of refugees following the 1968 Soviet occupation of Czechoslovakia found a relatively benign milieu here, as the Canadian film industry and education system was developing rapidly at the time. The generous acceptance of Czech film exiles ${ }^{(1)}$ was a reflection of the world-wide response to the Czechoslovak "film miracle" of the 60s and specifically also to that country's successful presentation at EXPO 1967 in Montréal. ${ }^{(2)}$ Probably the most distinct Czech "mark" in the history of Canadian audio-visual culture was made by the experimental work of Emil Radok who had become famous as the founder and representative of the so-called multi-screen show.

\section{I.}

Director, scriptwriter and producer Emil Radok (1918-1994) studied at the College of Chemistry and Technology in Prague before World War II; after the war he studied aesthetics at the Charles University. The blending of his technical, scientific and aesthetic abilities resulted in his unique artistic practice, which is also confirmed in this statement: "I got to art through studies of the exact sciences, mainly mathematics, chemistry, and my pleasure was to see theatre in a "molecular" way, to decompose reality into its smallest parts, some sort of atoms, and then set them into a new reality" (Cieslar, 1990: 6). Radok defined his analytic-synthetic method, which represented the basis of his pioneering experiments in the domain of advanced audio-visual forms. He himself called it a technique of creative "differentiation" and favoured cubism in cinema, rather then Griffith's parallel composition. He saw Eisenstein as the inventor of a new montage and rhythmical possibilities of film language (compare Reizes, 1986: 19).

Emil Radok significantly influenced Czech culture of the post-Stalinist era: he co-founded the Laterna Magica in Prague, which in an original way connected theatre performance with film projection. He shot non-traditional puppet films (Johannes doktor Faust, 1958; Don Špagát, 1960); the invention of the Polyekran (multi-screen) was his special domain. This simultaneous projection upon a system of separate screens had its origins in the Polyvision of Abel Gance (in Napoleon, 1926), but Radok, together with the architect Josef Svoboda, created a modern and highly sophisticated form of this system. Radok conceptualised Polyekran as a new synthetic form, which connected "the arts of film and architecture in such a way that the images, which are located in space and with their kinetic sequence within themselves, create a film story; and with their kinetic sequence among each other ... they create an architectonic story using movement harmonies" (in Grossman, 1961: 210).

The first Polyekran project, Pražské jaro (Prague Spring music festival), became a sensation at the EXPO 1958 World Fair in Brussels and was awarded the Expo Grand Prix. For a ten-minute promotion shot of the music festival, the film-makers used a system of eight suspended screens, on which films and slides were projected. Similar success was repeated at the EXPO 1967 in Montréal where Stvořeni světa (The Creation of the World) programme, a simultaneous projection from 224 slide projectors on 112 screens, was used. Radok continued to use this exclusive invention even after leaving for his Canadian exile in 1968. In Montréal, where he spent the rest of his life, he founded for this purpose the Research Institute of Advanced Audio-Visual Forms and Systems; but notably he carried out three more unique multi-screen projects. ${ }^{(3)}$

II.

Radok's first Canadian project was the Kaleidoscope Pavilion at the 1969 Montréal exhibition "Man and His World". The audiovisual show Circus Magic combined screen and live action. It introduced the character of a circus clown, who made comments on the world of humans though his pantomimic sketches. The buffoonery carried by a stream of playful visual variations was interrupted at the end by an image of an atomic mushroom cloud. The effect of the fifteen-minute movie was based on the creation of multiplication 
chains, which represent the indigenous principle of this genre. The movie was divided into three parts, projected in three rooms with reflective screens whose mirror effects were connected by associative assemblage processes. In the first hall the image was composed vertically, in the second horizontally, and in the third, they were integrated. The whole system was further enhanced by the interactive effect of (controlled) image movements and the (free) movement of spectators, who passed through the halls and took different, variable positions. ${ }^{(4)}$

The next project, Energy (1982), was created for the Energy Pavilion at Disney World's Epcot Center in Florida. Radok further experimented with the technical possibilities of multi-screen in combination with 3-D effect. ${ }^{(5)}$ The nine-minute clip was projected on one hundred suspended triangular prisms, one side white and another black. Through rotation, a three-dimensional effect was created, by modulating the profile of the screen and its mosaic structure. By turning all prisms with their white side towards the audience, a standard wide-angle screen was obtained. Variations could be created by turning some of the prisms with their black sides or edges facing the audience. ${ }^{(6)}$

Documentary shots of real objects were used to create variable pictorial patterns, which metamorphosed into an abstract collage of lights, movements and rhythms. Radok's method is illustrated in the following examples: "We assembled two shots of a Montréal arched bridge and one of the arches very impressively changed into an abstract image of a snake. Or we discovered a busy street that was splitting in two in one place because a house stood in the middle. We filmed cars passing by at night and the result was a beautiful image of some sort of necklace of lights" (Táborská, 2000: interview). Again, the spectators watched the production mostly standing in a wide shallow hall with benches along the walls. The film received widespread attention: in Time magazine it was described as a "radiant palette of images relating to natural and human energies. It is not hard to classify it as the most amazing film of the decade" (Corliss, 1986); the show remained at the Epcot Center for almost eighteen years.

\section{III.}

The biggest success was achieved by Radok's last work, The Taming of the Demons (1986, 23 min.). It was commissioned by Teleglobe Canada for the Canadian pavilion at Expo 1986 in Vancouver. One can describe the film as a documentary which surveyed the development of communication technologies, from the primitive drumming with a bone or cavern drawings, through the invention of printing press and mechanical devices of the nineteenth century, to the twentieth century with its computers and satellite transmitters.

However, the motif of the communication evolution was cleverly woven into an impressive dramatic construction of civilisation history revealing the clash of culture and nature - or the human race and the demons. Communication represents the basic premise and expression of life and the whole culture of mankind.

Radok created The Taming of the Demons in the purview of avant-garde or experimental film, uniting the means of non-fiction and fiction, documentary and drama, science and fantasy. His method was based upon the flexibility of new plastic techniques, resulting from technological innovations. In a mighty gesture the author transposed his vision of evolution into a vivid emblematic mosaic, which, in an elliptic abbreviation, depicted the rapid evolutionary metamorphoses.

The project worked with a system of spatially structured ten screens which - beside their changeable distance from the projector - also had different sizes and shapes. The result was, according to Radok, a sculpture in space: the locus was formed by a rotating ball (based on the strobe effect) surrounded by nine rectangular screens upon which images were projected from ten synchronised $35 \mathrm{~mm}$ projectors. The projection area changed from time to time depending on which screens were actually used. The visual layer was complemented by a soundtrack which consisted of music, stylised noise effects and a commentary, delivered on sixteen channels. This time around, the spacious projection hall had a traditional setting with fixed rows of seats.

A sophisticated loudspeaker set functioned not only as a technical tool to maximize the sensual effects, but also as a part of the programme's aesthetic system. The projection architecture could be understood as a symbolic representation of the solar system (the Sun and nine planets) suspended in the dark, endless and unknown universe ("black holes" between the screens and behind them). Planet Earth was shown here as part of a higher aggregate, a higher mysterious unity, from which everything is derived and to which 
everything is related again.

Due to its round shape and central position, the central screen had a special function which assumed symbolic connotations connected with the act of creation: at the beginning of the show, the light beam cut a white circle - a symbolic image of the maternal womb from which the initial energy issues, the primary genetic code. From this exposition, the leitmotif of a varied image of a DNA spiral unfolded, expressing the principle of evolution and on which rests the genetic relay of information.

The manipulated movement was a key element of the (spiralling) evolutionary process whose explosive nature was reflected in the kaleidoscopic film form loaded with dynamism and energy. The presentation was based on an expressive montage, multiplied by the resources of the simultaneous projection on several individual screens. This montage allowed not only the connection of non-consecutive images, but intensified the impression of plurality, dynamism and changeability of actions, as well as the sensual and intellectual potency of the work, requiring creative participation from the spectator.

Radok made a deconstruction of a given reality into visual fragments, which he reorganised in space-time juxtapositions into new dynamic structures, based on a rhythmical variation of multiple images and their re-compositions. The film therefore acquired the visual flow of varying and diversified forms, movements and shapes, in which real objects decomposed and re-composed in more or less abstract patterns.

The above- mentioned effects were achieved in several characteristic ways: synchronous multiplication of an identical picture in several different frames; movement directions (diagonal composition of flying planes); developing one scenic image in time and space (a figure running from frame to frame in the sequence with shamans and demons); by interconnecting parts of one pictorial motif across several screens (a spiral created by the semicircles of turning wheels); or by mirror duplication (two simultaneous horse riders whose tracks cross in the middle).

The Taming of the Demons was a vivid cosmogonic vision that put chaos at the outset - in the sense of Greek mythology and biblical tradition - from which order is born. Flashes start to cross the darkened screens followed quickly by successive images of raging elements: flying cumulus clouds; black matter penetrated by red sunshine; volcanic eruptions and rolling lava, which takes over the red motif and literally flows across the screens; a stormy ocean depicted by a countering centripetal movement of surging waves; windstorms. The whole sequence was accompanied by cacophonic chords of music and mysterious sounds of natural forces. The following key sequence, the shamanic taming of natural demons, was then dominated by a stylised ritual dance, which turbulently jumped from screen to screen accompanied by African drumming.

The modern epoch of the interconnected world was expressed by a chain of associations: typical architectural objects in the world's metropolises depicted on the margin al screens dissolve into heads of people of various races who talk to each other across an ocean spreading across the screens between them. Another variation of this idea was presented in a composition of modern fast trains, which emerge from the background of individual screens in a different phases until they cross in a big close-up. The world made smaller and accelerated by new technologies however, gives rise to new demons of civilisation, such as that evoked by the rapid-montage sequence: images chaotically shoot from the centre toward the edges with accelerating frequency.

This sequence highlighted the process of mankind's technological extension leading to the conquest of space and at the same time to a shrinking world. Its composition is related to the other sequence with the raging elements; both provide a perfect demonstration of the multi-screen system's ability to depict the process of cumulation and extension in space. A number of analogical (circle) images at the beginning and end of the film suggested a kind of closed evolution cycle: it began by breaking up the original unity and led to a vision of the world re-united by telecommunications, in which mankind - having tamed the natural demons - will win over the demons of civilisation. ${ }^{(7)}$

The film was very successful; millions of spectators saw it at the World Exposition alone (CP, 1987); the Academy of Canadian Film and Television gave The Taming of the Demons its Genie Award for the best Canadian film at EXPO '86. It was also praised by critics as "an unforgettable spectator's experience" (Frazer, 1985 /1986: 94) or Radok's "brilliant sense of form and radical imagination," which helped to originate "one of the best films of its kind" (Godfrey, 1986: C3). In 1989 the film projection was installed at 
the French popular- scientific Futuroscope Park in Poitiers, where Radok began to prepare his future project in Time Pavilion.

Jean-Claude Delorme, president of Teleglobe Canada, said: "Radok is probably in the area of audiovision what Marshall McLuhan was in literature" (In Frazer, 1985/1986: 92). Such comparison certainly had its reason, and not only because they both worked in Canada. The Taming of the Demons fully corresponded to McLuhan's thoughts on the technological extension of the senses and on the transformation effect of media and their impact on mankind. In fact, the film itself directly confirmed one of McLuhan's propositions that "the medium is the message:" regardless of its "content" The Taming of the Demons is a message about the taming of the demons of new communication systems.

In Canada, Emil Radok earned respect as an original creative mind, as testified by his assistant Antonín Lhotský:

He led a quite normal life, in a small flat; his wife cooked Czech food for him, and he liked to eat very much. But at work he completely changed into a totally concentrated, choleric autocrat; his colleagues often said that he was mad, not knowing what he wanted because this or that was impossible to achieve, but Radok always managed to accomplish his maddest visions. Personally we got on very well and I still appreciate very much that I had the chance to work with him. By the way, the producers, although they would not dispense with conflicts, always gratified his demands, because they also realised very well that Radok was simply irreplaceable (2000: interview)

Radok's exclusive stance made him one of the most important and at the same time most underrated creative artists in his branch, one of the last radical modernists in this post-modern world.

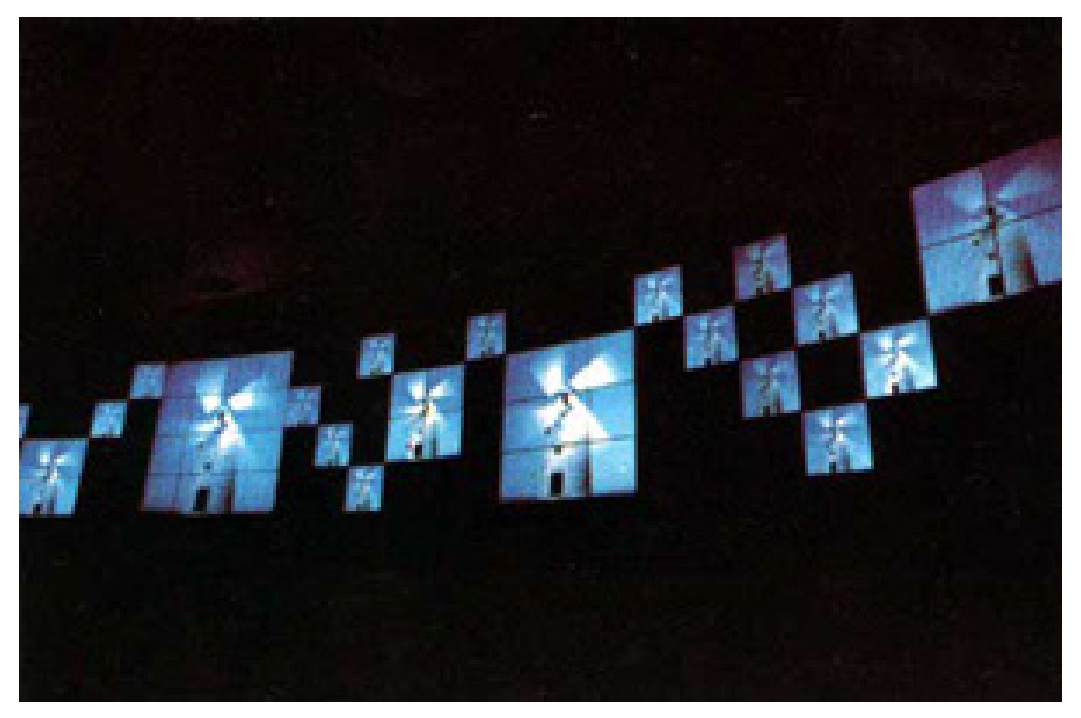

Figure 1: Radok's Energy

\section{Notes}

1. In the area of feature film and television there were significant appearances by actor Jan Rubes and his wife, actress and producer Susan Douglas, actress and pedagogue Maruska Stankova, script writer and actor Vladimír Valenta, music composer Milan Kymlička or director Ján Kadár. In non-fiction there were Dagmar Táborská (documentaries), Alice and Milo Kubík (puppet films produced by their own company Animette Canada) or Czechoslovak TV Company Okno-The Window (journalism and documentaries). A number of exiles dedicated their work to pedagogy: documentary maker Václav Táborský (Algonquin College in Ottawa, Conestoga College in Kitchener, York University in Toronto), cameraman Antonín Lhotský 
(York University), director and producer Milo Kubík (North York School Board's Audio-Visual Department in Toronto), film maker and photographer Vladimír Kabelík (Sheridan College) or theoretician Jan Uhde (University of Waterloo).

2. Much attention was achieved by experimental projects Polyvision, Diapolyekran and especially Cineautomat, which combined the projected film with a live actor in front of the screen and enabled the spectators influence the development of the story by voting for offered variants. (Compare McLuhan, Marshall: The Emperor's New Clothes. In: Through the Vanishing Point: Space in Poetry and Painting, where he directly cross-indexed to the Cineautomat principle.)

3. In Radok's projects also other film makers of Czech origin took part in key professions: Dagmar Táborská as editor of all three works, cameraman Antonín Lhotský (worked on the complementary shots for the Energy and as the director of photography on The Taming of the Demons) and architect Vladimír Šubert (designer of the audio-visual system for The Taming of the Demons).

4. Dagmar Táborská said with regard to the project: "It was a wonderful work. I could play so much with the material throughout the editing: for example the clown on a trampoline - I let him jump out of one picture and he came back in a different one. I did not even mind editing with my head in a special mirror box to see how the images will be reflected during the projection. The film was successful and our co-operation with Radok could go on" (2000: interview).

5. In Antonín Lhotský's opinion it was an "unbelievably complicated project", which was haunted by some production difficulties and we had to make some additional shooting: "The producers, Krivicky brothers originally from Poland, forced through a Polish cameraman, bud they did not get on well with Radok, so he called me. There were five synchronised cameras encompassing a wide angle, and the image from every camera was then projected upon twenty screens". The sophistication of the project was projected also in the unusually long time of its processing - one year and a half (2000: interview).

6. "We use the rotating screens for instance as a dissolve. For example: we made a big shot of a locomotive, which was supposed to cross from one screen to another. That required fraction-of-a-second's precision to reach the continuous movement. And it also required also absolute precision during each projection. If the projectors lost their synchronisation, though only minimally, it would have immediately diminish the right effect" (Táborská, 2000: interview).

7. The exceptional project was also exceptionally costly, which also related closely to Radok's style of work and his maximalist requirements: "Radok was a great perfectionist, he could be engaged with the smallest detail for a long time - for instance plumping feathers on the dancers' costumes, it would drive the producers crazy. A cardinal share of the about 2.5 million budget was swallowed already by the huge preparations and rehearsals, very expensive scene. For instance: we had a precise copy of the Altamira caves made in the studio. We also used an immense amount of film material, because each shot that Radok was not absolutely content with we redone again and again. Only the filming itself took three months. Also the copy-making was very complicated. In case when there was the same image on all three screens, sky for instance, it was necessary to have all ten copies developed so that they had absolutely the same colour tone, the same light intensity etc., the labs had to redo that many times before we reached a satisfactory result. On top of it, we had to have the whole set of copies made anew; during the projection we had to use abnormally strong lamps, because the black space among the screens swallowed light, and therefore the film was losing colour rapidly" (Lhotský, 2000: interview).

\section{References}

\section{Literature}

Cieslar, Jiří. "O Alfrédu Radokovi s jeho bratrem Emilem." Literární noviny (Prague), No. 15 (July 12, 1990), p. 6.

"Emil Radok." Literárni noviny (Prague), No. 6 (February 10, 1994), p. 11.

Clarke, Gerald. Canada Puts On a Fair That's Fun. Time, 1986, June 2. 
Corliss, Richard. If Heaven Ain’t a Lot Like Disney Theme Parks. Time, 1986, June 16.

CP. Expo presentation wins special award. The Globe and Mail, 1987, March 5.

Frazer, Robbin. "The Taming of the Demons." Performing Arts in Canada, Winter 1985/1986, pp. 92-94.

Godfrey, Stephen. Expo fun is about to begin. The Globe and Mail, 1986, April 12, p. C3.

Grossman, Jan. "Výtvarné hledisko Laterny magiky a polyekranu." Výtvarné umění (Prague), 11, No. 5, pp. 203-210.

Hedvábný, Zdeněk. Alfréd Radok. Zpráva o jednom osudu. Prague: Národní divadlo \& Divadelní ústav, 1994.

Jireš, Jaromil. "Co nového přináší polyekran." Film a doba (Prague), 1959, No. 5, pp. 352 - 354.

Kratochvílová, V. "Kdo je Emil Radok?" Kino (Prague), 1950, No. 13, p. 5.

Périgny, Louis. Teleglobe Canada at EXPO 86 (booklet, 1986).

Reizes, Stephen. "Emil Radok: Inventing a new language of cinema." Cinema Canada, July/August 1986, n. 132, p. 19.

-ta-. "Zkrocení démonů". Nový domov (Toronto), 1987, March 31.

\section{Interviews}

Antonín Lhotský: October 2000 (Toronto).

Dagmar Táborská: October 2000 (Toronto).

Václav Táborský: October 2000 (Toronto).

\section{Audio-visual material (videotapes)}

The Taming of the Demons (script: Emil Radok, Bob Barrett, Jasmin Simard, Pierre Sormany; director: Emil Radok; camera: Antonín Lhotský; editor: Dagmar Táborská; producer: Paul Krivicky; production: Applause Communications Montreal, 1986, 23 min.)

This study was produced as a part of grant project of the Grant Agency of the Czech Republic No. 408/00/1072.

\section{Author Information}

Jiří VORÁČ is Chair of the Film Studies, at the Department of Theatre and Film Studies, Faculty of Arts, Masaryk University Brno, Czech Republic. His area of specialization includes Czech film history after 1945, interpretation and adaptation issues and film criticism. He wrote the book Czech and Slovak Film Directors in Exile (Palacký University, Olomouc, CR), and has contributed reviews to Film a doba, Iluminace and other publications. 